\title{
SUITABILITY ASSESSMENT OF GRETAGEOUS LIMESTONES FROM THERMO (AITOLOKARNANIA, WESTERN GREECE) FOR THEIR USE AS BASE AND SUB-BASE AGGREGATES IN ROAD-CONSTRUCTION
}

\author{
Mpalatsas I., Rigopoulos I., Tsikouras B. and Hatzipanagiotou K. \\ Department of Geology, Section of Earth Materials, University of Patras, 26500 Patras, Greece, mpalat- \\ sas@upatras,rigopoul@upatras.gr,v.tsikouras@upatras.gr,k.hatzipanagiotou@upatras.gr
}

\begin{abstract}
This paper focuses on the assessment of mineralogical, petrographical and physico-mechanical properties of limestone formations in order to evaluate their suitability as road construction aggregates. Research focuses on Olonos-Pindos zone limestones of Creataceous age in Aitoloakarnania province, Western Greece. Special emphasis was given on comparing the mechanical properties to the mineral components. The results were evaluated in accordance with Greek and International suitability Standards for road construction aggregates. It was finally concluded that the physical and mechanical properties of the tested rocks are in compliance with the suitability Standards and that they can be used as road-construction aggregates.
\end{abstract}

Keywords: Aggregates, limestone, physico-mechanical properties, Thermo Aitoloakarnania.

\section{Introduction}

The increasing demand for crushed rock aggregates in various applications and especially the requirement for hard aggregates in numerous engineering projects of Greece, have increased the necessity for the detection of carbonate rocks which are suitable for the production of aggregates used for: bases and sub-bases, improvement layers, bituminous mixtures, concrete and embankments. Additionally, carbonate rocks are used in various environmental applications such as for erosion protection, for the stability of natural or artificial slopes and for filters (Spyropoulos, 2005).

This paper investigates potential aggregate resources from the Cretaceous limestone formations of the Olonos-Pindos zone. Six representative samples were examined (AT9A, AT9B, AT13A, AT13B, AT22), in order to determine their suitability as road bases and sub-bases. The quality of the collected limestones was assessed based on their physico-mechanical properties, as well as on their mineralogical and textural features.

\section{Geological setting}

The studied carbonate rocks of Thermo (Aitoloakarnania province, Western Greece) (Fig. 1), cover a total area of $37 \mathrm{~km}^{2}$. They comprise part of the lower unit (thickness more than $1000 \mathrm{~m}$ ) of the Olonos-Pindos zone, which includes pelagic limestones of Triassic to Upper Cretaceous age. These limestones are intercalated with radiolarites of Middle Jurassic to Lower Cretaceous. The Upper 


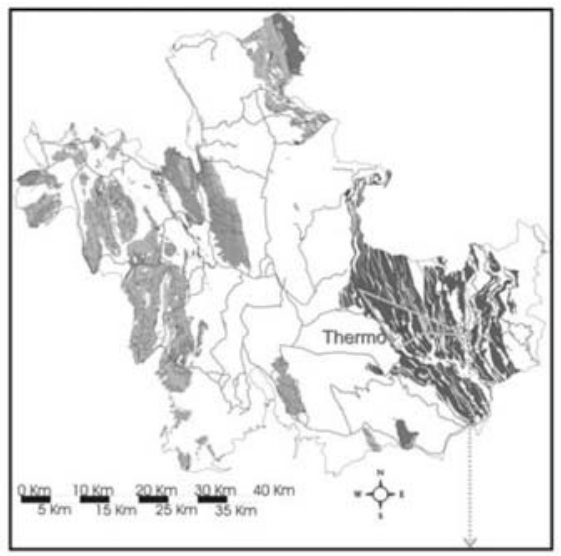

\section{LEGEND}

orizon of transition formations.

Alternations of limestones, sandstones and marls

EOCENE - PALEOCENE

Upper Cretaceous limestones

UPPER CRETACEOUS

Limestones and 'first flysch' formations

LATE CRETACEOUS

'Drimos' limestones

JURASSIC - UPPER TRIASSIC

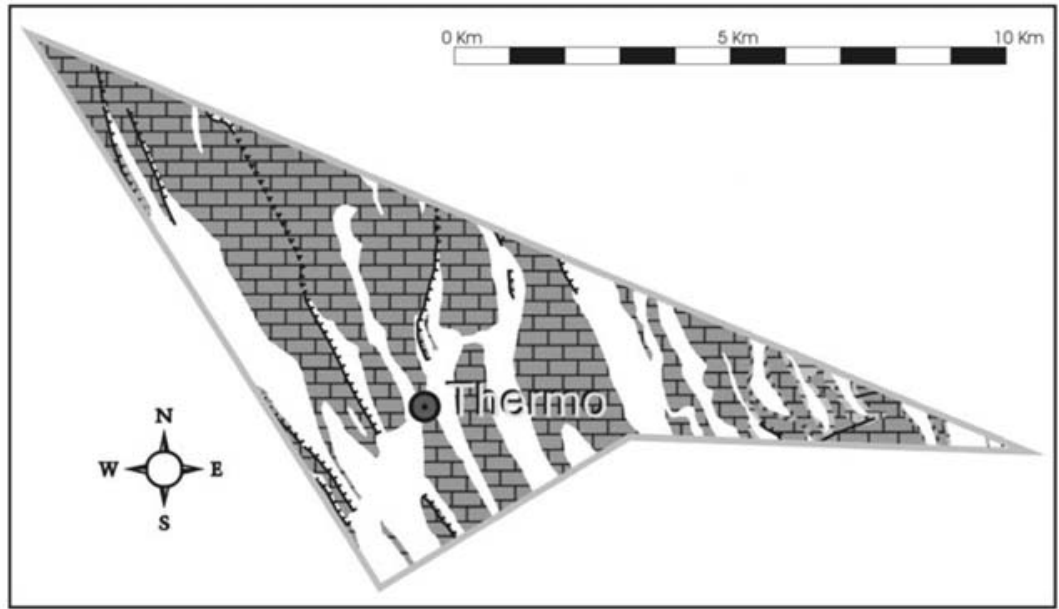

Fig. 1: Geological map of Thermo (Aitoloakarnania province). The general map is an extract from the "Thermo" map sheet, I.G.M.E. (1977).

Cretaceous limestones, which comprise the upper part of this lower unit, are biomicritic and mediumbedded with intercalations and nodules of flint. The colour of these limestones varies from gray to whitish and becomes reddish at the lower parts, while their thickness varies from 200 to $400 \mathrm{~m}$ (Katsikatsos, 1992; Mountrakis, 1985).

The Cretaceous carbonate rocks (Fig. 1) cover the greatest area $\left(34 \mathrm{~km}^{2}\right)$ among the formations of the Olonos-Pindos zone and occur in beds up to $20 \mathrm{~cm}$ thick. The rock slopes of the studied area are cut by joints with opening up to 3-4 $\mathrm{cm}$ and are characterized by manifold disruption and intense folding. All these features have led to local destruction of the original structure of these rocks (Fig. 1). Statistical analysis of the strike of the limestone beds revealed that the main direction strikes NNW - SSE and dips $15^{\circ}$ to $60^{\circ}$ to the ENE or WSW.

\section{Petrography}

The studied Upper Cretaceous carbonate rocks were collected from representative localities of quarry faces or natural slopes, with a view to be fresh and to represent the full variability of the quarry 


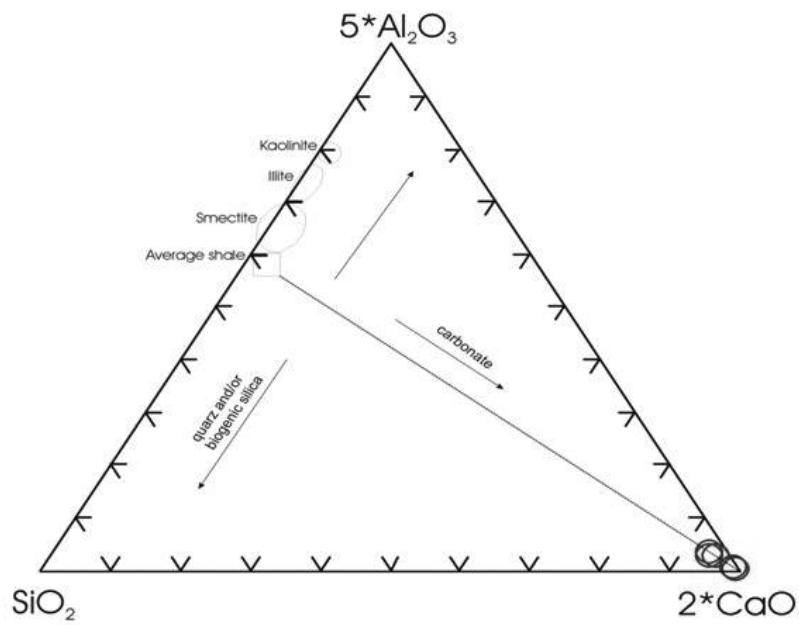

Fig. 2: Plot of the analysed samples on the $\mathrm{Al}_{2} \mathrm{O}_{3}-\mathrm{SiO}_{2}-\mathrm{CaO}$ diagram for sedimentary rocks.

products. Most of these rocks are macroscopically whitish to gray with a dense network of sparitic veins, except for samples AT9B and AT22B, which have a yellowish pink colour. The microscopic examination was carried out using polarized microscopy at the Laboratory of Research Mineral and Rocks, Department of Geology, University of Patras, as well as at the Laboratory of Electron Microscopy and Microanalysis, University of Patras. Petrographic examination indicated that samples AT9A, AT9B, AT13A and AT22B are micritic limestones and according to Folk $(1959,1962)$ are classified as packed biomicrites (AT9A) and sparse biomicrites (AT9B, AT13A and AT22B), whereas according to Dunham (1962) are classified as wackestone (AT13A and AT22B), bioclast packstone (AT9A) and bioclast mudstone (AT9B). Samples AT13B and AT22A are sparitic limestones and are classified as sorted biosparites (AT22A) and as sorted endobiosparites (AT13B) according to Folk, and as biograinstone (AT22A) and endobioclast grainstone (AT13B) according to Dunham (1962).

\section{Whole-rock geochemistry}

Whole-rock analyses in six representative Cretaceous carbonate samples are listed in Table $1 . \mathrm{TiO}_{2}$, $\mathrm{Fe}_{2} \mathrm{O}_{3}, \mathrm{MgO}, \mathrm{K}_{2} \mathrm{O}$ and $\mathrm{P}_{2} \mathrm{O}_{5}$ abundances are lower than the Greek and Global average values. Low $\mathrm{P}_{2} \mathrm{O}_{5}$ is a result of the absence of apatite, which frequently exists in carbonate rocks, while the low $\mathrm{TiO}_{2}$ values are related to the absence of detrital heavy minerals. $\mathrm{SiO}_{2}$ in three samples (AT9B, AT13A, AT22B) is higher than the Greek average value (1.80\%) whereas samples AT9A, AT13B $x \alpha$ AT22A show lower values. Samples AT9B, AT13A and AT22B are richer in $\mathrm{Al}_{2} \mathrm{O}_{3}$ relative to the Greek average value, most likely reflecting the occurrence of clay minerals. Samples AT9A, AT9B, AT13B $x$ a A AT22B are richer in $\mathrm{Na}_{2} \mathrm{O}$ relative to the Greek and Global average value probably due to the presence of anhydrite and feldspars. All samples are rather rich in $\mathrm{MnO}$ with the highest value in sample AT9A (0.07\%). Samples with higher $\mathrm{SiO}_{2}$ values show also lower loss-onignition values, reflecting the lower calcite abundances.

On an $\mathrm{Al}_{2} \mathrm{O}_{3}-\mathrm{SiO}_{2}-\mathrm{CaO}$ diagram (Fig. 2), the analysed samples plot close to the $\mathrm{CaO}$ apex, suggesting that they are poor in clay- and silicate-fraction. 


\section{Physiomechanical properties}

Several laboratory tests were performed for the suitability assessment of the Cretaceous limestones from Aitoloakarnania as aggregates (Table 2). These tests were carried out according to the American (ASTM) and Greek (ELOT) Standards. Selection of samples was based on their mineralogical composition that strongly controls the quality of aggregate materials (Zarif \& Tuğrul, 2003; Tsikouras et al., 2005; Pomonis et al., 2007). Physicomechanical properties were estimated in six representative samples, which include micritic (AT9A, AT9B, AT13A and AT22B) and sparitic limestones (AT13B xal AT22A).

\subsection{Physical properties}

Apparent density, bulk density (ASTM C-127), water-absorption (ASTM C-128) and sand equivalent (ASTM D-2419) were carried out. Normal density aggregates show values ranging between 2-3 $\mathrm{gr} / \mathrm{cm}^{3}$, which are broadly used in several construction works. Light-weighted aggregates have densities $<2 \mathrm{gr} / \mathrm{cm}^{3}$ whereas heavy aggregates are those with density $>3 \mathrm{gr} / \mathrm{cm}^{3}$. Apparent density in the analysed samples ranges from $2.68 \mathrm{gr} / \mathrm{cm}^{3}$ to $2.71 \mathrm{gr} / \mathrm{cm}^{3}$ and are classified as normal aggregates.

Water-absorption was estimated after 24 hours immersion of the samples in water and ranges between $0.40 \%$ and $1.30 \%$; samples AT9B AT22 have the maximum and minimum values, respectively.

Aggregates with sand equivalent values $>50 \%$ are considered suitable for base and sub-base aggregates in road constructions. The sand equivalent (AASHTO T176-65) ranges in the analysed samples between $63 \%$ and $78 \%$, suggesting their good quality.

\subsection{Mechanical properties}

The estimated mechanical properties according to Greek and international standards include the riprap soundness using $\mathrm{Na}_{2} \mathrm{SO}_{4}$ (ELOT EN 1097-01), the toughness and abrasion resistance using the Los Angeles abrasion test (L.A.A.V.; ASTM C 535), the uniaxial compression strength (ELOT 408), and the maximum Proctor density (E105-86). The results are listed in Table 2. The Los Angeles values range between $23.26 \%$ and $27.52 \%$, the riprap soundness $\left(\mathrm{Na}_{2} \mathrm{SO}_{4}\right)$ yielded values between $2.70 \%$ and $3.70 \%$, the uniaxial compression strength ranges between $49.30 \mathrm{MPa}$ and $68.00 \mathrm{MPa}$, and the maximum Proctor density is in the range of $2176-2207 \mathrm{kgr} / \mathrm{m}^{3}$.

Using linear regression analysis (Bevington \& Robinson, 2002) it is clearly shown that there is an antipathetic relation between the Los Angeles values and the uniaxial compressive strength values with a correlation coefficient $\mathrm{R}^{2}=0,8065$ (Fig. 3). Los Angeles values also plotted against the wholerock major oxides. $\mathrm{SiO}_{2}$ abundance shows positive correlation with the Los Angeles values, indicating that with increasing silica there is a decrease in the rock quality (Fig. 4); similar behaviour is also suggested with increasing $\mathrm{Al}_{2} \mathrm{O}_{3}$ contents. The Los Angeles values show also significant positive correlation with the riprap soundness values (Fig. 5), revealing that the more durable in toughness and abrasion a rock is the more durable in weathering under variable climatic conditions. Finally, a moderate correlation between the Los Angeles values and the maximum Proctor density values is observed in the analysed (Fig. 6).

\section{Discussion}

Mineralogical and textural characteristics, as well as the degree deformation and porosity are some critical factors in the quality of aggregates (Hartley, 1974; Kazi \& Al-Mansour, 1980; Al-Jassar \& 
Table 1. Whole-rock geochemical analyses of representative samples from Cretaceous limestones from Thermo (-: below detection limit)

\begin{tabular}{|c|c|c|c|c|c|c|c|c|}
\hline $\begin{array}{c}\text { Major elements } \\
(\text { wt } \%)\end{array}$ & AT9A & AT9B & AT13A & AT13B & AT22A & AT22B & $\begin{array}{c}\text { Global } \\
\text { Average } \\
\text { Value }\end{array}$ & $\begin{array}{c}\text { Greek Av- } \\
\text { erage } \\
\text { Value }^{2}\end{array}$ \\
\hline $\mathrm{SiO}_{2}$ & 0.81 & 3.22 & 3.33 & 0.52 & 0.72 & 2.29 & 5.20 & 1.80 \\
\hline $\mathrm{TiO}_{2}$ & - & 0.02 & 0.01 & - & - & 0.01 & 0.07 & - \\
\hline $\mathrm{Al}_{2} \mathrm{O}_{3}$ & 0.14 & 0.78 & 0.62 & 0.08 & 0.15 & 0.59 & 0.80 & 0.50 \\
\hline $\mathrm{Fe}_{2} \mathrm{O}_{3}{ }^{\mathrm{A}}$ & 0.08 & 0.40 & 0.32 & 0.10 & 0.10 & 0.31 & 0.50 & 0.50 \\
\hline $\mathrm{MnO}^{\mathrm{MgO}}$ & 0.07 & 0.04 & 0.05 & 0.05 & 0.05 & 0.05 & 0.05 & 0.02 \\
\hline $\mathrm{CaO}^{\mathrm{Na}}$ & 0.40 & 0.37 & 0.36 & 0.31 & 0.56 & 0.39 & 7.90 & 2.80 \\
\hline $\mathrm{K}_{2} \mathrm{O}$ & 53.96 & 53.32 & 53.84 & 57.34 & 53.56 & 53.71 & 42.60 & 51.60 \\
\hline $\mathrm{P}_{2} \mathrm{O}_{5}$ & 0.07 & 0.07 & 0.05 & 0.08 & 0.1 & 0.07 & 0.05 & 0.05 \\
\hline $\mathrm{LOI}$ & 43.30 & 41.77 & 41.92 & 40.32 & 43.57 & 42.50 & & \\
\hline $\mathrm{Total}$ & 98.83 & 100.21 & 100.53 & 98.81 & 98.91 & 100.00 & & \\
\hline
\end{tabular}

${ }^{1}$ Mason \& Moore (1982), ${ }^{2}$ I.G.M.E. (1997)

Table 2. Results of the physicomechanical properties of the analysed samples from Thermo

\begin{tabular}{|c|c|c|c|c|c|c|}
\hline Sample No. & AT9A & AT9B & AT13A & AT13B & AT22A & AT22B \\
\hline Bulk density $\left(\mathrm{gr} / \mathrm{cm}^{3}\right)$ & 2.69 & 2.69 & 2.71 & 2.70 & 2.70 & 2.68 \\
\hline Apparent density $\left(\mathrm{gr} / \mathrm{cm}^{3}\right)$ & 2.65 & 2.63 & 2.66 & 2.66 & 2.64 & 2.66 \\
\hline Water absorption $(\%)$ & 0.80 & 1.30 & 1.10 & 0.9 & 1.20 & 0.40 \\
\hline Los Angeles $(\%)$ & 23.26 & 25.79 & 27.50 & 24.55 & 27.11 & 27.52 \\
\hline Riprap soundness $(\%)$ & 2.70 & 3.40 & 3.70 & 3.20 & 3.70 & 3.50 \\
\hline Uniaxial compressive strength $(\mathrm{MPa})$ & 68.00 & 58.85 & 49.30 & 55.00 & 50.00 & 51.00 \\
\hline Sand equivalent $(\%)$ & 68 & 63 & 69 & 70 & 73 & 72 \\
\hline Maximum Proctor density $(\mathrm{kgr} / \mathrm{m} 3)$ & 2176 & 2192 & 2201 & 2176 & 2207 & 2189 \\
\hline
\end{tabular}

Hawkins, 1991; Smith \& Collis, 2001; Jensen et al., 2010).

Apparent and bulk density of the Creatceous limestones from Thermo show moderate to slightly high values and are within the acceptable limits of aggregates suitability (NBG 1985, Shakoor et al. 1982, Cargill, 1989). Water absorption is another important factor related to durability of the materials. Experimental results have shown that rocks with water absorption values higher than $3 \%$ are vulnerable to shock changes of temperature (Shakoor et al., 1982). Samples AT9B (1.3\%), AT13A $(1.10 \%)$ and AT22A (1.20\%) show the highest water absorption values compared to the rest samples, most likely due to their higher porosity and participation of clay minerals that strongly absorb 


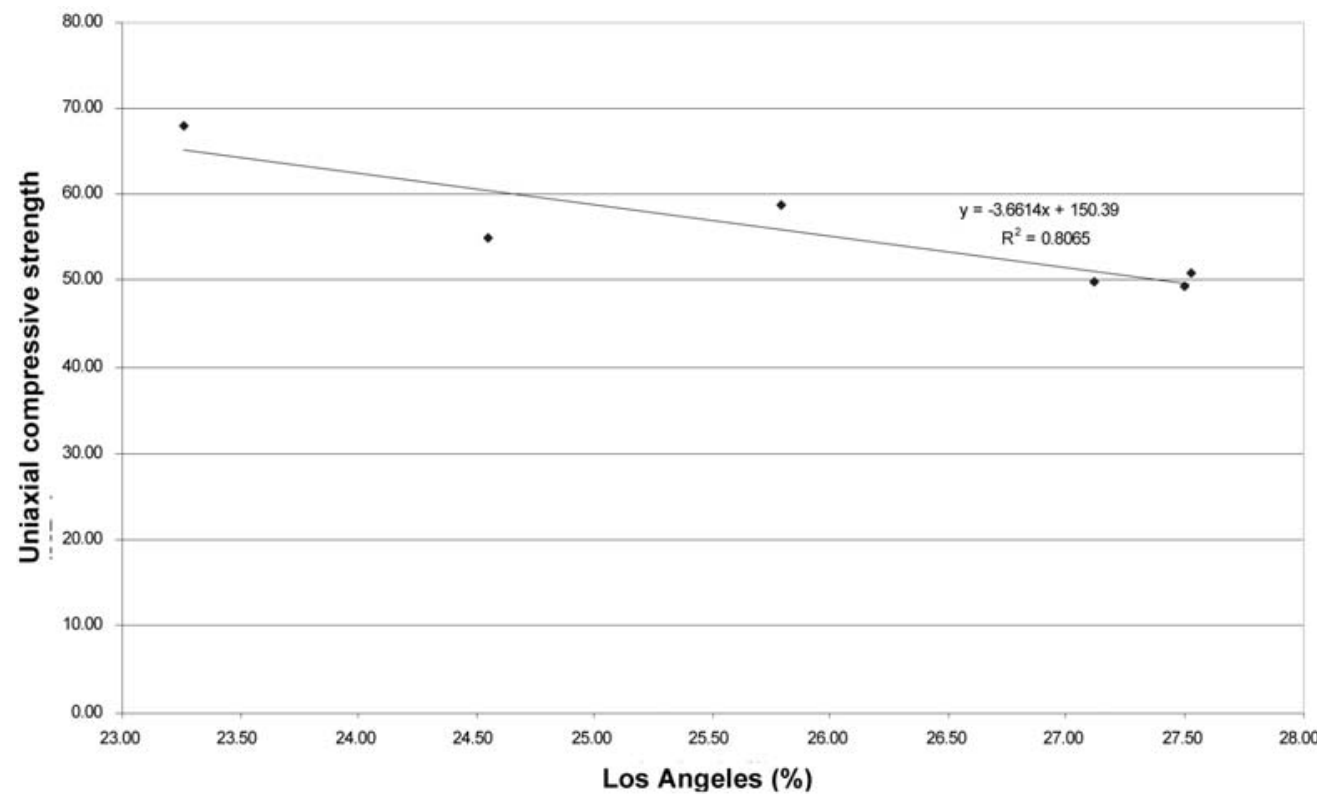

Fig. 3: Plot of Los Angeles values vs. uniaxial compressive strength values of the analysed samples from Thermo.

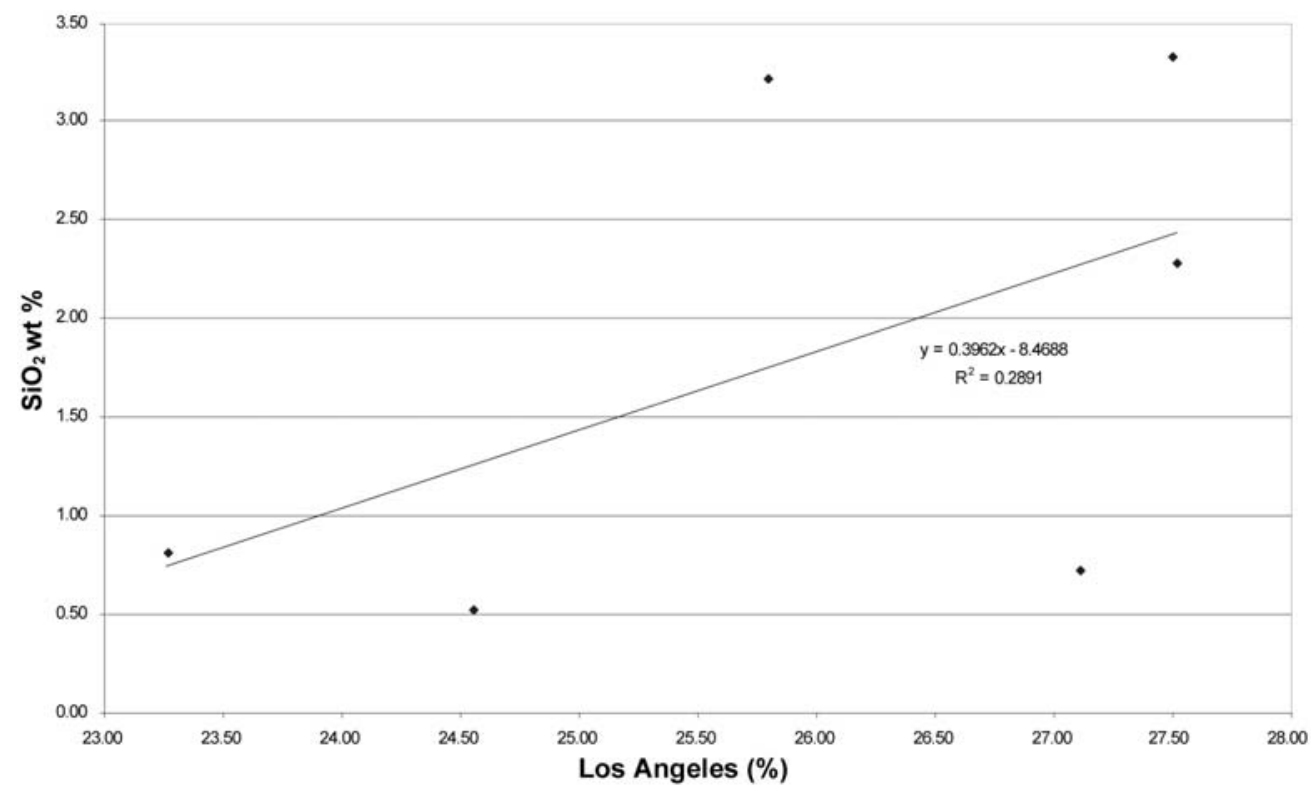

Fig. 4: Plot of Los Angeles values vs. $\mathrm{SiO}_{2}$ contents of the analysed samples from Thermo. 


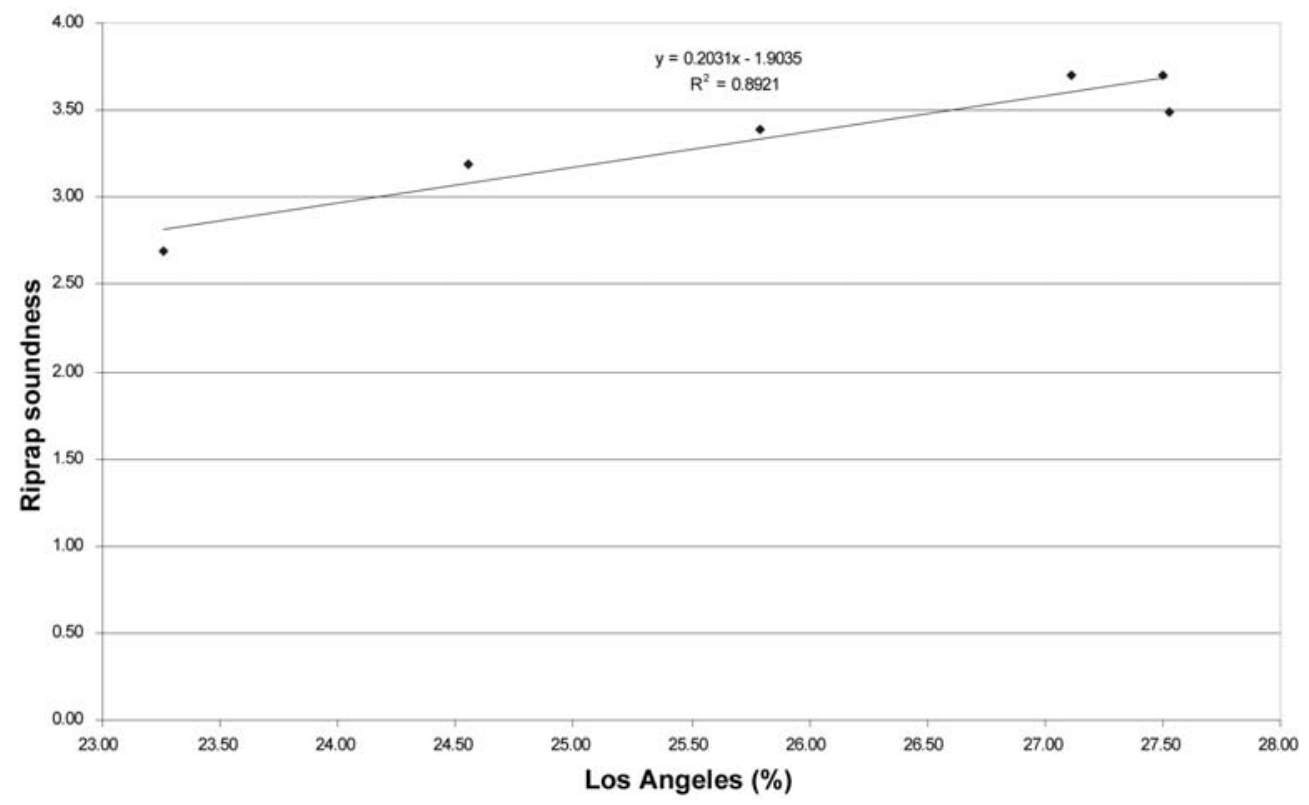

Fig. 5: Plot of Los Angeles values vs. riprap soundness using $\mathrm{Na}_{2} \mathrm{SO}_{4}$ of the analysed samples from Thermo.

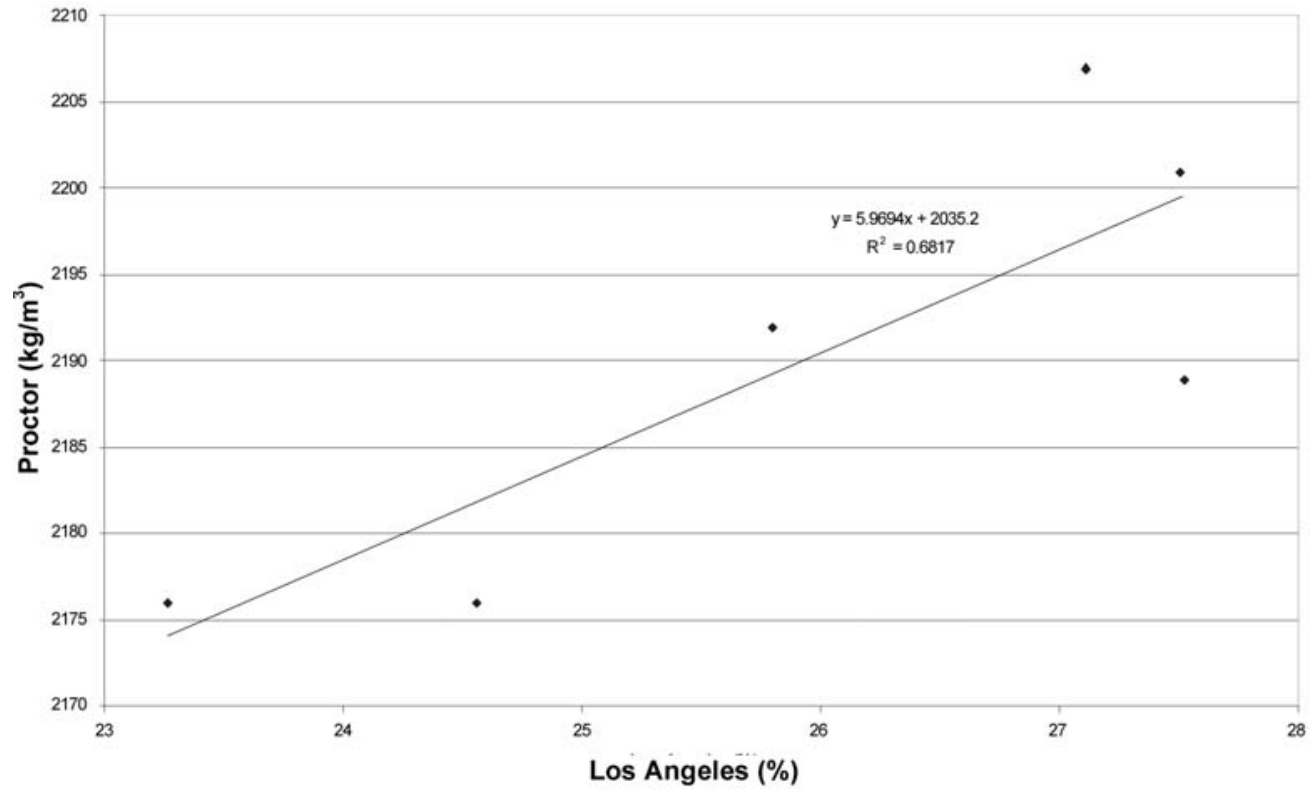

Fig. 6: Plot of Los Angeles values vs. maximum Proctor density of the analysed samples from Thermo. 
water. A test that simulates the volume changes of aggregate materials and estimates their durability under climatic variations is the soundness of riprap (Smith \& Collis, 2001). For this purpose, it is used $\mathrm{Na}_{2} \mathrm{SO}_{4}$ or $\mathrm{MgSO}_{4}$, which crystallize in the pores and joints of the aggregates and disintegrate them after repeated freeze-thaw and dry-wet cycles (Bloem, 1966). In this study, we used a $\mathrm{Na}_{2} \mathrm{SO}_{4}$ solution and the obtained riprap soundness values of the Cretaceous limestones are below the limit of 12, for their use as bases and sub-bases in road construction

The Los Angeles values are low whereas the sand equivalent values are high in the analysed Cretaceous limestones from Thermo. According to the standards of the Greek Ministry of Environment the upper limit of Los Angeles and the lower limit of sand equivalent, for the suitability of aggregates for road construction works, are 30 and 50, respectively. Our samples clearly fulfill these prerequisites and hence it is strongly suggested that they are suitable for use as bases and sub-bases aggregates. The somewhat higher Los Angeles values of samples AT22A and AT22B are interpretaed as the result of their sparitic texture (e.g. Zarif \& Tuğrul, 2003; Sabatakakis et al., 2008).

\section{Conclusions}

Petrographic investigation in Cretaceous limestones from Thermo showed that they comprise rocks with both micritic and sparitic textures; they are intensely tectionised and frequently they are cut by joints filled with recrystallised calcite. Geochemical analyses reveal that they contain insignificant impurities and are similar to the Greek and Global average limestones. Physicomechanical properties such as Los Angeles, soundness of riprap, uniaxial compressive strength and maximum Proctor density are correlated each other. Moreover, there is a positive correlation of the Los Angeles values with the $\mathrm{SiO}_{2}$ abundance in the rocks. Therefore, knowledge of some of these parameters can easily predict the quality of the aggregates.

The studied rocks show values of their physicomechanical properties within the acceptable Greek and international limits and hence they are suitable for their use as bases and sub-bases aggregates in road construction works.

\section{References}

Al-Jassar, S. \& Hawkins, A.B., 1991. The Carboniferous Limestone of the Bristol area: a review of the influence of the lithology and chemistry on its use as a geomaterial. Quarterly Journal of Engineering Geology and Hydrogeology, p. 24, 143 - 158.

Bevington, P.R. \& Robinson, D.K., 2002. Data reduction and error analysis for the Physical sciences, 3rd ed.,p. 320 .

Bloem, D.L., 1966. Soundness and deleterious substances. ASTM STP 169A, p. 497-512.

Cargill, J.S., 1989. Evaluation of Empirical Methods of Measuring the Uniaxial Compressive Strength of Rock, Unpublished Thesis, Department of Geology, Kent State University, Kent, OH. p. 80.

Dunham, R. J., 1962, Classification of carbonate rocks according to depositional texture. In: Ham, W. E. (ed.), Classification of carbonate rocks: American Association of Petroleum Geologists Memoir, p. 108-121.

Folk, R.L., 1959. Practical petrographic of limestone. Bull. Am. Ass. Petroleum Geologists, p. 43, 1-38.

Folk, R.L., 1962. Spectral subdivision of limestone types. In W.E. Ham (ed), Classification of carbonate rocks. Am. Assoc. Petroleum Geologists, Memoir, p. 1, 62-84.

Hartley, A., 1974. A review of the geological factors influencing the mechanical properties of road surface aggregates. Quarterly Journal of Engineering Geology and Hydrogeology, p. 7, 69-100. 
I.G.M.E., 1977. Geological map of Greece, Thermo sheet. I.G.M.E., Athens.

Jensen, L.R.D., Friis, H., Fundal, E., Møller, P. \& Jespersen, M., 2010. Analysis of limestone micromechanical properties by optical microscopy. Engineering Geology, p. 110, 43-50.

Katsikatsos, G., 1992. Geology of Greece. University of Patras, p. 451.

Kazi, A. \& Al-Mansour, Z.R. 1980: Influence of geological factors on abrasion and soundness characteristics of aggregates. Engineering Geology, p. 15, 195-203.

Mason, B and Moore, C.B., 1982. Principles of geochemistry, New York, J. Wiley \& Sons, p. 344.

Mountrakis, D., 1985. Geology of Greece. University Studio Press, Thessaloniki, p. 207.

NBG (Norwegian Group for Rock Mechanics), 1985. Engineering Geology and Rock Engineering. Handbook No. 2, p. 249.

Pomonis, P., Rigopoulos, I., Tsikouras, B. \& Hatzipanagiotou, K., 2007. Relationships between petrographic and physicomechanical properties of basic igneous rocks from the Pindos ophiolitic complex, NW Greece. Proceedings of the $11^{\text {th }}$ Conference of the Geological Society of Greece, p. 947-958.

Sabatakakis, N., Koukis, G., Tsiambaos, G. \& Papanakli, S., 2008. Index properties and strength variation controlled by microstructure for sedimentary rocks. Engineering Geology, p. 97, 80-90.

Shakoor, A., West, T.R. \& Scholer, C.F., 1982. Physical characteristics of some Indiana argillaceous carbonates regarding their freeze-thaw resistance in concrete. Bulletin of the Association of Engineering Geologists, p. 19, 371- 384.

Smith, M.R. \& Collis, L., 2001 . Aggregates: Sand Gravel and Crushed Rock aggregates for Construction Purposes, Geological Society, London Eng. Geol., Special Publication, 17, p. 339.

Spyropoulos, A., 2005. Investigation of the engineering-geological conditions in the Achaia prefecture related to search of aggregates for various uses. PhD Thesis, Univ. Patras, p. 306.

Tsikouras, B., Pomonis, P., Rigopoulos, I. \& Hatzipanagiotou, K. (2005). Investigation of suitability of basic ophiolitic rocks from Mikrokleisoura, Grevena, for their use as antiskid aggregates and railway ballast. Proceedings $2^{\text {nd }}$ Congress of the Committee of Economic Geology, Mineralogy, and Geochemistry of the Geological Society of Greece, p. 347-356.

Zarif, I.H. \& Tuğrul, A., 2003. Aggregate properties of Devonian limestones for use in concrete in Istanbul, Turkey. Bulletin of Engineering Geology and the Environment, p. 62, 379-388. 